\title{
Voluntary Organisation and the Role of Ramakrishna Mission in Shillong
}

\author{
Moupali Deb \\ Department of Sociology North Eastern Hill University India
}

\begin{abstract}
Today voluntary organisations are playing an active role in almost every conceivable field of human interest. Their contribution to the welfare and development of a society is undoubtedly remarkable. By fostering a sense of solidarity among its members, a voluntary organisation provides an opportunity to serve ones fellows and the society at large without being motivated by profit. They work on philanthropy, spiritual and altruistic principles. Along with their immense contribution in diverse field such as education, relief, rehabilitation etc, the role of voluntary organisations in human development by improving our health system cannot be ignored The study focuses on the role played by voluntary organisations in India and by the Ramakrishna Mission as a voluntary organisation in particular. It also highlights the activities of Ramakrishna Mission relating to health in Shillong with emphasis on its charitable dispensary and its mobile medical unit.
\end{abstract}

Keywords: Dispensary, Health Sector, Medical, Ramakrishna Mission, Voluntary organisation,

\section{INTRODUCTION}

Taking care of the sick, feeding the hungry, providing shelter to the homeless, giving financial aid to the poor and acts alike have been a part of the Indian culture and value system since time immemorial. Guided by the feelings of compassion and charity such spirit of serving ones fellow beings found its roots in the religious beliefs of the people. Infact an important feature of almost all the religions is the emphasis it places on the act of helping others particularly the poor and needy. This is evident in Hinduism, Buddhism, Jainism and Sikhism where dana (giving) is considered as an important part of one's dharma (religion). In Islam while charity (Zakah) has been made binding on all adherents, in Christianity it is an act of love. However as society began to evolve such works of charity were increasingly taken over by voluntary organisation which are increasingly engaging itself in various sectors of social life like relief, rehabilitation, health, education, women and child development programmes, poverty amelioration, environmental conservation, slum improvement and so on. Today deriving its strength more from the community than religion these organisations seek to identify and work for the neglected, marginalised and weaker sections of the society including children, women, scheduled castes and tribes, backward classes in need of help or issues which have failed to receive government's attention. Voluntary organisations extend support to their beneficiaries in a number of ways, from providing financial aid, to provision of services or facilities, through guidance and counseling or by providing support to other organisations. Their range of activity in a democratic setup is so extensive that it has become impossible to overlook their contribution to the welfare and development of a country. While many voluntary organisations operate at the national and even international level, there are also others which operate in a specific region or locality. Among the major voluntary organisations, are orphanages, hostels, homes for the aged and the handicapped, etc. In the category of education schools, colleges, non-formal and adult education centers fall. Health organisations comprises of hospitals, dispensaries, health centre and outreach programmes. The paper will briefly touch upon the meaning of voluntary organisation along with the history of its evolution in India with emphasis on the activities carried out by the Ramakrishna Mission as a voluntary organisation in the area of healthcare delivery in general and in Shillong in particular. The article draws information from both primary and secondary sources.

\section{MEANING OF VOLUNTARY ORGANISATION.}

The term 'voluntarism' is derived from the Latin word 'voluntas' which means "will" or "freedom". In the most basic sense a voluntary organisation consists of a group of people who come together to fulfill some purposes. David.L.Sills defines it as an organised group of persons (1) that is formed in order to further some common interest of its members (2) in which membership is voluntary, neither mandatory nor acquired through birth and (3) that exist independent of the state(Sills1968:371). According to Michael Banton it is a group organised for the pursuit of one interest or of several interests in common. Usually, it is contrasted with involuntary groups serving a greater variety of ends, such as kin groups, castes, social classes and communities (Sarkar 2005:36). In Beveridge's, words "a voluntary organisation is an organisation in which whether its 
workers are paid or unpaid, is initiated and governed by its own members without external control"(Sarkar 2005:36). The following are the essential characteristics of a voluntary organisation.

(i) These organisations are free from any external control and are governed by its own members on democratic principles.

(ii)Have definite objectives and programmes which are humanitarian in nature.

(iii)Not profit oriented.

(iv)Managed by an independent self governing body elected periodically by the members.

(v)Have a formal legal status.

(vi) Have a clearly defined constitution.

(vii) The funding is generally done by the local communities, donors or sometimes even by the governmental organisations.

The active force which enables the voluntary organisations to perform its designated functions are the volunteers who offer their services without any financial compensation. The volunteers contribute to the working of the organisation through their personal experiences and professional expertise and the honorary services rendered by them enables the organisation to provide services at a low cost and in many cases even free. Their close interaction with the population enables the organisation to get a closer understanding of the needs of the target group and thus receive active participation in the programmes. Volunteers join such organisation either because it gives them a sense of fulfillment by serving others or provide a means by which they can demonstrate an active concern for the community. Professor Muttalib's observed that there are five main sources of voluntarism- religion, government, business, philanthropy and mutual (Madan 2004:70). Bourdillon and William Beveridge viewed mutual aid and philanthropy as the two main sources from which voluntary social service organisations emerged(Madan2004:70). The other factors motivating voluntary action could be cited as personal interest, seeking benefit such as experience, recognition, knowledge and prestige, commitment to certain values etc.

In the Indian context the terms mostly used to describe these initiatives include 'voluntary initiatives', 'voluntary associations', voluntary agencies', 'voluntary organisations', etc. A major impetus for the use of this terminology derives inspiration from Mahatma Gandhi who played a pivotal role as a propounder of voluntary efforts in the rural development of the country.

\section{HISTORY OF VOLUNTARY ORGANISATIONS IN INDIA}

\section{Before independence:}

Voluntary organisation is not a new phenomenon in India it has always been a part of its culture and tradition. According to R.C.Majumdar (1961), "in ancient and medieval periods the kings, merchants, landlords and various corporate organisations vied with one another, according to their means for helping the cause of religion." Emperor Asoka organised free kitchens and free shelter to the needy poor. The religious institutions such as temples, maths, dharamshalas etc later became the centers of social service on an extensive scale. During the Mughal period, as a rule, citizens had to pay $1 / 40^{\text {th }}$ of their unspent wealth as tax (zakat), which was used for charitable purposes( Madan 2004:71).

In the British era, with the efforts initiated by enlightened Indians, a large number of voluntary organisations sprang up. The social work activities undertaken by the voluntary workers during the British period passed through various phases. The first phase from 1780 to 1880 was devoted to social reforms. In the second phase, from 1880 to 1900 , the emphasis was laid on the establishment of social welfare agencies for the socially handicapped. In the third phase, from 1900 to 1920, there was formation of all-India organisations especially for the Harijans, tribals and industrial workers. In the fourth phase, from 1920 to 1937, the emphasis was on the preventive aspect, i.e. expansion of educational facilities, village uplift and development of industries, provision for recreational activities and protective legislation. In the fifth phase, between 1937and 1939 , the new short lived Congress ministries in many states set up rural development and/ or women's welfare departments for rural reconstruction and welfare of women respectively(Madan 2004:71-78).

\section{After independence:}

India has witnessed a tremendous growth in the number and influence of voluntary organisations since independence in 1947. The processes of grassroot democratisation as well as the economic policy of liberalisation have been the major forces behind the growth. Since Independence until around 1980 there was little effort on the part of the Indian Government to define the role of a voluntary agency or to recognise its importance. In 1980, with the Sixth Five Year Plan (1980-1985), the government identified new areas in which these organisations could participate in development. These areas included:

(a) Optimal utilisation and development of renewable source of energy, including forestry through the formation of renewable energy association at the block level. (b) Family welfare, health and nutrition, education and relevant community programs in the field. (c) Health for all programs. (d) Water management and soil 
conservation. (e) Social welfare programs for weaker sections. (f) Implementation of minimum needs program. (g) Disaster preparedness and management. (h) Promotion of ecology and tribal development, and (i) Environmental protection and education( Madan 2004:74).

Under the Seventh Five Year Plan (1985-1990) the Indian government envisioned a more active role for voluntary organisations to aid in making communities as self-reliant as possible. These groups were expected to show how village and indigenous resources could be used and how human resources, rural skills and local knowledge could be used for their own development. In the Eight Five Year Plan its importance was further enhanced, paying particular attention to the role of these agencies as participants in rural appraisal for drawing up developmental plans at a very low cost and involving the rural community.

\section{HEALTH AND HEALTHCARE SCENARIO IN INDIA}

The medical scene in India has been undergoing tremendous change since the past few decades. While on one hand the disease patterns have changed and new concepts of health care and medicines have evolved on the other technological advancements have made medicines and treatment procedures extremely expensive and beyond the reach of common people. While ailments such as poliomyelitis, leprosy and neonatal tetanus will soon be eliminated, infectious diseases such as dengue fever, hepatitis, whooping cough, respiratory infections, tuberculosis, malaria and pneumonia continue to plague India. Further due to the adoption of unhealthy dietary practices by the affluent urban population India is experiencing a rising trend in non- communicable/ lifestyle diseases such as hypertension, cancer and diabetes. India is ranked third among countries with HIV-infected patients. Poor sanitation and inadequate safe drinking water is leading to diarrheal diseases the primary causes of early childhood mortality. As more than 122 million households have no toilets as over $50 \%$ of the population defecate in the open(2008 estimate) leading to a number of diseases through parasitic and bacterial infections. Maternal deaths are also high owing to socio-economic and cultural constraints limiting access to care. A considerable rural-urban imbalance in terms of accessibility is also witnessed in which the rural population is still struggling for better and easy access to health care and services. There are also shortages of hospital beds and trained medical staff such as doctors and nurses.

Under the Indian Constitution, health is a state subject. Each state therefore has their respective healthcare systems in which both public and private sectors operate. Certain responsibilities are also undertaken by the Central government, relating to the working of various health authorities and providing funds to implement national programmes. The organisation at the national level consists of the Union Ministry of Health and Family Welfare (MoHFW). In each State, the organisation is under the State Department of Health and Family. Each regional/zonal set-up covers 3-5 districts and acts under authority delegated by the State Directorate of Health Services. The healthcare infrastructure in India includes levels that include primary, secondary or tertiary healthcare providers. The providers of healthcare at these different levels include:

Public Health Sector

(i)Primary health care- Primary health centres, sub- centres.

(ii) Hospitals and health centres-rural hospitals, community health centres, specialist hospitals, medical college hospitals, municipal hospitals.

(iii) Health insurance schemes-Central Government Health Schemes, Employee State Insurance Scheme etc

(iv) Other Agencies- defence, railways.

Private Sector

(i) For profit - Private hospitals, dispensaries, nursing homes, clinics, polyclinics and general practitioners.

(ii)Non profit- charitable trusts by temples and educational institutes and NGOs.

(iii)Indigenous Systems of Medicine (AYUSH)

(iv)Ayurveda, Yoga, Unani, Siddha and Homeopathy.

(v) Voluntary Health Agencies like Indian Red Cross, Indian council of child welfare and many more

(vi)National Health Programmes like National Cancer Control Programme, National Program of Healthcare for the Elderly etc

From the above mentioned components of the Indian healthcare system the public and private health sector are the dominant. While $74 \%$ of hospital beds are contributed by the private sector. $25 \%$ of the population is covered by public and private insurances. The composition of expenditure is shown below:

HEALTH EXPENDITURE PUBLIC AND PRIVATE \% OF GDP

\begin{tabular}{|l|l|l|l|l|l|l|l|l|l|l|}
\hline & 2005 & 2006 & 2007 & 2008 & 2009 & 2010 & 2011 & 2012 & 2013 & 2014 \\
\hline Public & 1.13 & 1.11 & 1.1 & 1.16 & 1.22 & 1.16 & 1.18 & 1.18 & 1.29 & 1.41 \\
\hline Private & 3.15 & 3.14 & 3.13 & 3.18 & 3.15 & 3.12 & 3.16 & 3.21 & 3.24 & 3.28 \\
\hline
\end{tabular}

Source: http://www.worldbank.orghttp://data.worldbank.org/indicator/SH.XPD.PRIV.ZS and http://data.worldbank.org/indicator/SH.XPD.PUBL.ZS (accessed on 19 ${ }^{\text {th }}$ July 2016). 
It has been found out that while services provided in public hospital costs fraction of the private hospitals patients still prefer private hospitals as lack of good administration and management, deficiencies in the quality of services, unavailability of medicines and even diagnostic tests creates problems in accessing the care in public hospitals. The private hospitals on the other hand though are more accessible are not affordable by all. Further their concentration in urban areas makes it difficult for rural people to access them. Thus the major problem with the Indian healthcare system is accessibility, affordability and quality care. Voluntary organisations play a significant role here by helping not only to bridge the gap but also by creating a low-cost and effective health care model. The activities undertaken by such organisations include providing primary health care to people who do not have access to health services, reach remote areas which are poorly served by government and private facilities, assisting the government in its treatment campaigns and disease control programmes and devise innovative approaches for disease control. According to a rough estimate, today more than 7,000 voluntary organisations are operating in various areas of health care throughout the country. They encourage diversified participation in which charitable institutions, religious organisations, individuals and institutions participate actively through donations and collaborations. Alok Mukhopadhyay (2000:334) mentions the following types of voluntary health efforts that exist in India:

(i)Specialised Community Health Programs: running income-generation schemes for the poorer communities so that they can meet their basic nutritional needs.

(ii)Integrated Development Programs: In these programs, health is a part of integrated development activities.

(iii)Health Care for Special Groups of People: This includes education, rehabilitation and care of the handicapped.

(iv)Government Voluntary Organisation: These are voluntary organisations which play the role of implementing government programs like Family Planning and Integrated Child Development Services

(v)Health Work Sponsored by Rotary Clubs, Lions Clubs and Chambers of Commerce: They usually concentrate on eye camps - conducting cataract operations in the rural areas on a large scale with the help of various specialists, etc.

(vi)Health Researchers and Activists: The efforts of these groups are usually directed towards writing occasional papers, organising meetings on conceptual aspects of health care and critiquing government policy through their journals (which usually have limited circulation).

(vii)Campaign Groups:These groups are working on specific health issues,such as a rational drug policy and amniocentesis, among others.

\section{RAMAKRISHNA MISSION AS A VOLUNTARY ORGANISATION}

The Ramakrishna Mission is a voluntary organisation, dedicated to serving humanity. It was established in Kolkata on May 1897 by the lay and monastic disciples of Sri Ramakrishna, jointly, under the initiative of Swami Vivekananda. Vivekananda was deeply moved by the misery of India's poor and illiterate masses and established the Mission to pass on the teachings of Ramakrishna with emphasis on social service. It is a registered organisation under the India's Society's Act (XXI) of 1860 in which monks and devotees inspired by the ideals of service and renunciation conducts various types of social service activities. The headquarters of the Ramakrishna Mission is located at Belur in Howrah, West Bengal. At present the Mission has 181 branches in different parts of India and abroad. There are also about one thousand unaffiliated centres (popularly called 'private centres') all over the world started by the devotees and followers.

The various activities that the mission carries out in the diverse areas of human needs are briefly discussed below (Atmapriyananda 2010:146-151).

(i)Relief and Rehabilitation activities - Since its foundation in 1897, the Ramakrishna Mission has been conducting extensive relief operations in various parts of the country for the victims of natural disasters such as cyclone, flood, earthquake and man- made calamities such as riots.

(ii)Health care and Health education- The Mission runs hospitals, outdoor dispensaries and mobile dispensaries (mostly in rural and tribal areas). Besides medical camps are also conducted where people are treated free of cost.

(iii)Educational activities- Institutions like school, colleges, universities etc have been opened to impart knowledge of secular subjects.

(iv)Spread of religion and culture- This is accomplished through a large number of libraries, seminars, exhibitions, publishing books etc. There are 21 publishing centres publishing several books and 22 journals in different languages.

(v) Youth welfare programmes- Separate recreational and cultural centres for children and youth have been set up by the centres in Bangalore, Chennai, and Pune etc. Here the children are provided with supplementary nutrition and guidance in the practice of social, moral and spiritual values.

(vi) Women welfare programmes-The women are served through maternity sections in hospitals, old age homes, schools of nursing and vocational training centres for rural women. 
(vii)Work in rural and tribal areas- In these areas the Mission runs institutes of agriculture and rural development training institutes. Educational and medical institutions are opened in semi- urban areas where rural people form the bulk of the beneficiaries. The urban centres of the Mission have taken up development projects in rural and tribal areas such as wasteland development, construction of pucca houses are also undertaken. Some centres also conduct Pallimangal (integrated rural development) activities in selected villages.

\section{THE ROLE OF RAMAKRISHNA MISSION IN HEALTH SECTOR.}

The Ramakrishna Mission has set up a number of regular medical institutions such as hospitals or out patient dispensaries to cater to the medical needs of the people. Apart from the centres engaged solely in medical service, the various centres have started charitable outpatient dispensaries which subsequently developed into well equipped dispensaries providing allopathic and/or homeopathic treatment. Many of these centres also provide ayurvedic treatment, physiotherapy, accupunture etc. The hospitals get benefitted by equipments and other grants from State and Central governments besides public donations. One of the recent developments has been the introduction of Mobile Medical Units by a number of these centres, in order to extend medical services to people in remote corners of rural and tribal areas which are mostly inaccessible. These mobile units supply free medicines to a large number of patients, and organise free diagnostic and eyeoperation camps. Besides, preventive and promotive measures are undertaken through health education and immunisation schemes / programmes on a regular basis. The centres in Aalo (Along), Antpur, Chapra, Cherrapunjee, Coimbatore Mission, Ichapur, Jayrambati, Kamarpukur, Kalady, Malliankaranai (Tamil Nadu), Manasadwip, Mysore, Narainpur (Chhattisgarh), Narottam Nagar, Nattarampalli, Ramharipur, Sargachhi, Sarisha, Shivanahalli (Bangalore), Viveknagar (Agartala), Thrissur, etc, directly caters to the needs of rural and tribal folk (Atmapriyananda 2010:143).

Activities undertaken by the Ramakrishna Mission in various years in Health Sector:

\begin{tabular}{|l|l|l|l|l|l|l|}
\hline & $2004-2005$ & $2005-2006$ & $2006-2007$ & $2008-2009$ & $2009-2010$ & $2011-2012$ \\
\hline Hospitals & 15 & 15 & 15 & 15 & 15 & 15 \\
\hline Dispensaries & 125 & 129 & 121 & 125 & 130 & 129 \\
\hline $\begin{array}{l}\text { Medical } \\
\text { Mobile Units }\end{array}$ & 48 & 49 & 52 & 54 & 59 & 60 \\
\hline $\begin{array}{l}\text { Eye and } \\
\text { Other medical } \\
\text { camps }\end{array}$ & 80 & 75 & 89 & 450 & 790 & 1,038 \\
\hline $\begin{array}{l}\text { No of } \\
\text { Beneficiaries }\end{array}$ & 7897624 & 8277076 & 8540760 & 7918930 & 8079426 & 7823397 \\
\hline
\end{tabular}

Source-http://www.belurmath.org/activities.htm\#Medical and http: //vivekanandaarchive.$o r g\left(\operatorname{accessed}\right.$ on $30^{\text {th }}$ July 2016)

As part of their programme of service to the sick and the ailing, the Mission also runs two old-age homes, five nurses training centres, and a Medical Research Centre attached to the hospital in Kolkata for postgraduate degree and diploma students and an Institute of Paramedical Courses.

Some of the specialised medical treatments provided by some of the centres through their hospitals, dispensaries, special programmes, camps etc are mentioned below (Atmapriyananda 2010:140):

(i) Eye treatment rendered by the centers at Belgaum, Bhopal, Patna, Rajkot, Porbandar, and so on, and at the hospitals in Lucknow, Muzaffarpur,Vrindaban, etc. Many centers have separate eye- department attached to their dispensaries.

(ii)Leprosy case detection and treatment are done in centres at Lucknow, Kamarpukur, etc.

(iii)Maternity and child welfare services are provided by the hospitals in Kolkata, Lucknow, Thiruvananthapuram and Vrindaban and also by some dispensaries.

(iv)Neurology department functioned at the hospitals in Itanagar, Kolkata, Lucknow etc.

(v)Physiotherapy treatment provided by the centres in New Delhi, Indore, Itanagar, Kolkata, Lucknow, Nagpur , Shillong, etc. The centres at Rajkot and Vishakapatnam have special clinics for providing physiotherapy treatment to cerebral palsied children.

(vi)Psychiatry treatment provided in Thiruvananthapuram, Kolkata, Vrindaban, and Lucknow hospitals and also by some dispensaries.

(vii)Tuberculosis cases are treated at sanitorium in Ranchi, the TB clinic attached to Delhi centre and also in centres at Bhopal,Chennai, Lucknow, Patna etc. 
Many centres have special departments for dental surgery, ENT, cardiology, paediatrics, acupressure, acupuncture, etc. Many centres provide ayurvedic treatment. A number of medical camps for health awareness, dental care, child care, general medicines, etc are organised where patients are treated free of charge.

\section{HEALTHCARE DELIVERY IN SHILLONG}

Termed as 'Scotland of the East' the city of Shillong was founded by Col. Henry Hopkinson, Commissioner of Assam in 1864. It is the capital city of the state of Meghalaya as well as the District headquarters of East Khasi Hills District .Shillong is the 330th most populous city in India with population of 143,007 according to the 2011 census .Khasis make up the majority of the population making up 46.49 percent of Shillong population at 2011 census.

Though the foundation of treatment and healthcare centres in Shillong was laid by Christian Missionaries way back in the nineteenth century a large section of the population is still uncovered by health care services owing to hilly terrain and poor transport and communication network. Diseases such as kala-azar, malaria, leprosy, tuberculosis and various water borne diseases continue to affect people particularly those living in rural and forested areas. A large section of the population is also faced with the problem of acute shortage of safe drinking water leading to a number of chronic diseases. Today the city has a number of hospitals both private and public to cater to the medical needs of the people. The major ones being Civil Hospital, Ganesh Das Hospital, K J P Synod Hospital, NEIGRIHMS, North Eastern Institute of Ayurveda \& Homoeopathy (NEIAH), R P Chest Hospital, Wood Land Hospital, Nazareth Hospital, Christian Hospital etc. In addition to the above mentioned hospitals there are also a few other institutions, which provide only outdoor services or deal with specialised subjects only. The two of the better known are:

1) Ramakrishna Mission Dispensary, Shillong.

2) Sanker Nursing Home, Shillong, for Mental Health Care Services.

Besides, there are a number of dispensaries in the rural areas, mainly run by Christian missionaries.

\section{CONTRIBUTION OF RAMAKRISHNA MISSION IN HEALTH SECTOR,SHILLONG}

The history of Ramakrishna Mission in Shillong can be traced to 1901, when Swami Vivekananda along with his disciples visited, Guwahati and Shillong. But it was about twenty three years after the visit of Swami Vivekananda in this region, that the actual work started in 1924 when Swami Prabhananda, a young man inspired by Vivekananda's ideas moved up to the Khasi Hills to do something to help the tribals. With the help of a medical assistant in the Government Dispensary, he explained the object of his visit to the leaders of the village who readily welcomed the idea that the Ramakrishna Mission should work among the Khasis and soon a primary school was established at Shella, $115 \mathrm{kms}$ from Shillong with their help. He introduced homeopathic and bio-chemical medicines and improved methods of potato cultivation which was the staple food of the people staying there .

With the expansion of work it was decided to build a branch of Ramakrishna Mission in Shillong so that the entire activities of Ramakrishna Mission could be administered. As the growth of the work spread over the whole district, the Mission decided in 1949 to recognise it under two separate centres- one at Shillong with its temple , preaching work, library, charitable dispensary and one primary school, and the other at Cherrapunji with its High School, hostel and other feeder institutions located in inaccessible villages near about .

The number of patients served by the Charitable dispensary (Allopathy and Homeopathy departments) and the Mobile medical Unit during the period 2005-2013 is shown in the following table:-

\begin{tabular}{|l|l|l|l|l|l|l|l|l|}
\hline & $2000-06$ & $2006-07$ & $2007-08$ & $2008-09$ & $2009-10$ & $2010-11$ & $2011-12$ & $2012-13$ \\
\hline $\begin{array}{l}\text { Charitable } \\
\text { Dispensary }\end{array}$ & 83,066 & 91,053 & 80,946 & 80,300 & 80,255 & 67,131 & 61,886 & 61,296 \\
\hline $\begin{array}{l}\text { Mobile } \\
\text { Medical } \\
\text { Unit }\end{array}$ & 29,426 & 30,002 & 29,427 & 20,454 & 12,952 & 11,338 & 20,333 & 24,723 \\
\hline
\end{tabular}

Source: Records of Ramakrishna Mission, Shillong

\section{THE CHARITABLE DISPENSARY , SHILLONG}

The present Charitable Dispensary, the foundation of which was laid in 1951 was formally opened on $2^{\text {nd }}$ February 1952 (Ramakrishna Mission General Report- 1989-90). The activities of this Dispensary first began in the form of a small homeopathic dispensary in the Ashrama premises in the 1950s. But as the number of patients increased and the space in the Ashrama premises became insufficient to accommodate the inflow, a new 
dispensary building was raised on a plot at a little distance from the Ashrama with some financial donations from devotees and pinewood donated from the Department of Forests. The dispensary was inaugurated by the then Governor of Assam, Sri Jairamdas Daulatramji. In the year 2006, the Dispensary was shifted to its present multistoried premises to accommodate more patients.

\section{Activities of the Charitable Dispensary in Shillong}

Over the years, the facilities improved, with the establishment of a laboratory for pathological tests where routine tests of blood, lungs, nerve and vein, heart, optical tests are carried out. The laboratory is equipped with fully computerised and latest technological services which includes (a) Q.B.C. (malaria detection equipments), (b) Auto Cell Counter (c) Auto analyser for blood and urine Biochemistry. The Dispensary also has an X-Ray Unit, E.C.G. and Ultrasonography units. An Eye department, E.N.T. Department, General Medicine Section and Homeopathy department has also been introduced with increasing demand.

Being charitable in nature the dispensary has been rendering highly subsidised medical services to large number of incoming patients. The patients however have to pay a nominal fee to the receptionist for appointment which goes to the Mission's fund which is utilised for various developmental activities .A minimal amount is also charged for conducting of various tests. The charges in this case are fixed and different tests have different rates.

A monastic member looks after the day to day administration of the Dispensary. He is assisted by a band of dedicated staff. There are about 30 doctors in the Dispensary. Beside doctors the other staffs offering their services include ward boys, receptionist, and persons dealing with the carrying out of various tests like Xray, blood test and so on. While many offer their services on a purely honorary basis others receive salary. The Dispensary for its maintenance and operation are funded by donations received from individuals and corporate bodies. The doctors are appointed by the monastic incharge of the dispensary after consultation with the Secretary of the Mission branch in Shillong.

\section{The mobile medical unit}

Ramakrishna Mission embarked upon a programme, in 1961, of providing basic healthcare facilities to surrounding areas of Shillong for the benefit of tribal population, who could not cover long distances to meet their medical requirements. The mobile medical unit takes doctors, medical staff and volunteers with medicines to distant villages and renders free medical services to the people on a weekly basis.This was a welcome project as otherwise; the areas being remote, healthcare facilities had not reached the people.

One of the features of the Ramakrishna Mission Charitable Dispensary, Shillong is its achievement of the best possible results and a high standard of service- both technical and humanitarian- with the least possible expenditure. This is partly due to the honorary services offered by local medical practitioners. The personal care taken by the mission authority adds to this economy and efficiency.

\section{CONCLUSION}

The Ramakrishna Mission was started in Shillong with the objective of serving the tribal section which constituted the major portion of the total population. The medical services that are being carried out by the Ramakrishna Mission Charitable Dispensary, Shillong for the benefit of the tribal society proves this point. Ever since its inception in 1951 the Charitable Dispensary with its well equipped Clinical and Pathological laboratory, X-Ray, Surgical Sections and Homeopathic Department has been serving the local population. The tribal populations of the neighbouring villages are served with a mobile medical van which provides medicines to patients and baby food to children. It has been found that out of the total number of patients served by both the medical units, $80 \%$ constitute the Scheduled Tribe, 5\% Scheduled Caste and 15\% General approximately every year. True to the ideal of the organisation, the Charitable Dispensary of the Ramakrishna Mission has been seeking in its humble way to serve the people of this hill station.

In 1901 Swami Vivekananda said "Who on seeing the tiny sprout of the banyan can imagine that in course of time it will develop into a gigantic banyan tree?......". The banyan tree that he had seen as a 'tiny sprout' and envisioned as a 'gigantic banyan tree' has indeed turned out to be true. That 'tree' is the Ramakrishna Mission - a voluntary organisation, which is spreading its branches to serve the people in India as well as the rest of the world. The Shillong centre of The Ramakrishna Mission is also marching ahead by providing selfless voluntary service to the society.

\section{REFERENCE}


[1]. Anheier, Helmut and Regina List.2005. A Dictionary of Civil Society, Philanthropy and the Non - Profit Sector. London: Routledge.

[2]. Activities of the Ramakrishna Math and Ramakrishna Mission. http://vivekanandaarchive .org/mobile/monastic_order_detail.php?id=2 (accessed on $19^{\text {th }}$ July 2016).

[3]. Activities of Ramakrishna Math and Ramakrishna Mission, http: //www .Belurmath .org / activities.htm\#Medical ( accessed on $30^{\text {th }}$ July 2016)

[4]. Atmapriyananda, Swami. 2010. Ramakrishna Mission - A Saga of Service for a hundred years and more.Kolkata.: Belur Math.

[5]. Atmapriyananda, Swami. 2010. Ramakrishna Mission- Foundation Day Commemoration (Volume-I). Kolkata: Belur Math.

[6]. Direct response, India's Healthcare System -Overview and Quality ,Improvements, https:/ www . tillvaxtanalys. se/download/18.5d9caa4d14 d0347533bcf42e/ 14309097738 26/ direct _ response_2013 04.pdf (accessed on $23^{\text {rd }}$ August 2016)

[7]. Gambhirananda, Swami. 1957. History of Ramakrishna Math and Ramakrishna Mission. Calcutta: Advaita Ashrama.

[8]. Health and Health Care Services in Meghalaya, Meghalaya Human Development Report 2008 http://www.undp.org/content/dam/india/docs/human_development_report__ meghalaya_ 2008_full_report.pdf (accessed on $19^{\text {th }}$ August2016)

[9]. Health expenditure, private (\% of GDP), http: //data. worldbank. org/indicator/ SH.XPD. PRIV.ZS (accessed on $19^{\text {th }}$ July 2016).

[10]. Health expenditure, public (\% of GDP) http: //data. worldbank.org /indicator /SH. XPD. PUBL .ZS (accessed on $19^{\text {th }}$ July 2016).

[11]. Health in India, https://en.wikipedia.org/wiki/Health_in_India (accessed on 30th July 2016)

[12]. Khajuria, R.R.1996. Directory of Voluntary Social Organisations. Jammu: Discovery Publishing House

[13]. Lal, K. B. 1973. Contemporary Indian Philosophy. New Delhi: Motilal Banarsidass Publishers Pvt Ltd .

[14]. Lyons,Mark.2001. The Contribution of Nonprofit and Cooperative Enterprises in Australia- Third Sector. Australia: Allen and Unwin Ltd.

[15]. Madan, G. R.2004. Indian Social Problems (Vol-2).New Delhi: Allied Publishers Pvt Ltd.

[16]. Mohanty,Manoranjan and Anil K. Singh. 2001. 'Voluntarism and Government- Policy, Programme and Assistance'. Planningcommission.nic.in/reports/sereport /ser /stdy _ voluntary.pdf (accessed on $19^{\text {th }}$ August 2016)

[17]. Mukhopadhyay,Alok.2000.'Public- Private Partnership in the Health Sector in India', fin Yidan Wang (ed) Public-Private Partnerships in the Social Sector- Issues and Country Experiences in Asia and the Pacific ( 334-335 ).Tokyo: Asian Development Bank Institute

[18]. Munavalli,J.R , Merode,F.V .Dr, Rao, S.V .Dr and Srinivas, A. Dr. 2014. Healthcare of India: Today and Tomorrow. International Journal of Innovative Research and Development. Volume 3 (2): 351-354 www.ijird.com/index.php/ijird/article/download/47256/38296 (accessed on 21st August 2016)

[19]. Sarkar, Asok.2005. NGO's-The new Lexicon of Health Care.New Delhi: Concept Publishing Company.

[20]. Sills, David. 1968. International Encyclopedia of Social Sciences. USA: The Macmillan Company and the Free Press.

[21]. Status of the Voluntary Sector in India- A Study Report. http://www. vaniindia. Org I update/Inside \% 20Pages\% 20Status\% 20Voluntary\%20Sector\% 20dt\% 2022-6-13.pdf (accessed on $1^{\text {st }}$ August2016) 